\title{
ON THE DEMONOLOGY OF PLOTINUS
}

\section{Marju Lepajõe}

It is a common fact that the impact of the philosophy of Plotinus $(204 / 5-270)^{1}$ on the Eastern and Western philosophy as well as to the Christian theology ${ }^{2}$ has been immense. Considering that it seems paradoxical that the philosophy of Plotinus has been undertaken systematically and perhaps even comprehensive in the last 20 years only. During this short period of time more research papers have been written about him than during the whole one and a half millennium following his death. The flow broke loose after the final completion of the new text-critical 3-volumed issue of Plotinus' Enneads by Paul Henry and Hans-Rudolph Schwyzer (1973), ${ }^{3}$ which is "undoubtedly the most important contribution to Plotinian scholarship since Porphyry published the Enneads"4 and which has been called with a certain specific hauteur the first scientific edition of Plotinus' works. ${ }^{5}$ The Lexicon Plotinianum (1980) ${ }^{6}$ compiled by John Sleeman and Gilbert Pollet has contributed to the study of Plotinus likewise.

All 54 treatises of Plotinus have not attracted equal attention. Some treatises have been constantly reissued with new comments attached, and quite frequently two separate commentaries are issued concurrently. At the same time, there are a small number of treatises that have attracted little or no attention at all, not to mention the republications with comments. ${ }^{7}$

One of such 'unnoticed' ones is the 4th treatise of the III Ennead (15th in the chronological order), entitled (by Plotinus' disciple Por-

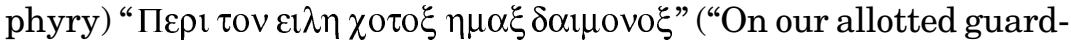
ian spirit") The treatise has been quoted in several contexts, its main theme - Plotinus' treatment of daimon ${ }^{8}$ - however, has been rarely mentioned. But bearing in mind the comprehension of the philosophical and religious demonology prevailing during the first three centuries BC, as it was formulated by Martin Nilsson in his monograph Geschichte der griechischen Religion, ${ }^{9}$ the treatment of daimon by Plotinus appears highly unique as compared to the contemporary multicolored, yet one-sided demonology. 
There are different explanations to why the III.4 treatise has not aroused much interest. One of them refers to the obscure circumstances of the origin of the treatise, the historians of philosophy suspect it to be associated with the sc. 'superstition in an unrespectable manner'. Porphyry narrates in his biography of Plotinus (Vita Plotini, ch.10):

An Egyptian priest came to Rome once and made acquaintance with Plotinus through a friend; the priest wanted to test his powers and suggested Plotinus to make the daimon that was born with him visible by conjuring. Plotinus gave a ready assent and conjuration took place in the Temple of Isis; because it was, as it is told, the only 'pure' place the Egyptian could find in Rome. When the daimon was conjured to reveal itself, a god appeared who was not one of the daimons. And the Egyptian is said to have called out: "Blessed are you, because a god is by you as your daimon and not some low class daimon!" But there was no opportunity to ask anything from the apparition or look at it longer; because a friend who was watching and holding birds in his hands to keep the purity of the place, squeezed them to death, be it out of envy or vague fear.

Eric Robertson Dodds argues ${ }^{10}$ that the story is historically irrelevant. Porphyry's source was neither Plotinus nor any immediate 'eyewitness'. The event is said to have taken place at least 35 years before Vita was published.

Nevertheless, E. R. Dodds finds the story remarkable in the history of Greek religion on two reasons: 1) the idea of the daimon who turns out to be a god is original (besides the extract above, the idea occurs only in the works of the 6th century Platonist Olympiodorus $\left.{ }^{11}\right) ; 2$ ) the idea of the birds mentioned who are held in hand to protect purity is also unique. The birds mentioned are most probably domestic hens being the holy birds who drive off the darkness as well as daimons.

In addition to the vague circumstances the treatise is hypothetical in its nature. Plotinus, in fact, poses a question whether it is possible that the daimon of a human is a god. He reaches the conclusion: why not? It might be possible. 
The third reason why the treatise remains unnoticed on the background of the bulky body of Enneads is the fact that while speaking about the daimons in his treatises Plotinus seems to rely on the treatments of daimons characteristic to his contemporaries; also, his phrasing does not strike as astonishing (sooner or later, however, he reveals all his mythological and religious notions in the hypostatic hierarchy of his system).

Plotinus, for instance, expresses the difference of the daimons and gods in his treatise III.5 "On Love" $(6,9)$ in a way characteristic to the contemporary world:

Now we speak and think of the race of gods as without affections or passions, but we attribute affections and passions to the daimons; we say that they are eternal next after the gods, but already inclining towards us, between gods and our race. At the same place he specifies $(6,19)$ : But it is better not to call any being in the intelligible world a daimon, but, even if there is an idea of a daimon, we should call this a god.

Under the same chapter he redefines the quality of daimons in more detail $(6,45)$ : they are $v o \eta \tau \eta v \lambda \eta$ 'an intelligible matter', the transition to the terrestrial materiality.

Plotinus view daimons as bodies of air or fire (III.5.6, 38) ${ }^{12}$, also a characteristic conception of his contemporary world. In his treatise IV.3 "On Difficulties About the Soul" he argues that the daimons speak (18, 22-24): There is nothing absurd in the daimons and spirits using their voice in air space, they are, after all, living creatures of a particular kind. Daimons and gods are beautiful (I.6), daimons can not witness the magic procedures with indifference (IV.4.43, 12), they can employ magic themselves (IV.4.30, 30), and they take their revenge (IV.8.5, 23).

Thereby Plotinus carries on a controversy with the Gnostics' conception of the daimons of malady (II.9 "Against the Gnostics" 14, 14):

If they [---] wish to purify themselves from maladies, as they say, they would do a right thing if they carried out the purification by living in temperance and regularity, just as the philosophers 
do; they, on the other hand, see maladies as demonic creatures and hope that they can negotiate them out of the bodies.

In the treatise under discussion we are facing two different methods of treatment of daimon. And that in this treatise only, because elsewhere we can find mere hints of different method of treatment characteristic to Plotinus. The occurrence of such two methods of treatment does not necessarily mean that they oppose each other, rather they form, as is characteristic to Plotinus, a compatible synthesis.

The first method of treatment is widely known, traditional, whereby the notion of daimon is clearly rendered worthless, characteristic already to Plutarch. Plotinus views the corporal world and Hades as the domain of daimon. Everyone standing outside these domains, remaining earthly, has exceeded the daimonic nature and 'the fortune by coincidence' of heimarmene. If the soul is unable to isolate itself it belongs to the realm of daimons, if its able to do it, it belongs to the intelligible divinity.

Trying to define the second the strictly plotinic method of treatment, we should first and foremost emphasize that the demonology of Neoplatonists originates from Plato's texts of two kinds: ${ }^{13}$

1) The Symposium (202d-e), where Plato refers to Eros as a daimon and argues that every daimoinion stands between the god and the human, being the mediator between gods and humans, imparting the prayers and sacrifices of humans to the gods and passing on orders and rewards vice versa; daimoinion serves as the connecting link, so that everything would be connected to everything else. That is because god does not interfere with humans, he speaks to them through daimoinion.

2) Extracts of text where Plato views daimon as a personal daimon: Republic (X book), Phaedo and Timaeus. According to this method every soul has its own daimon, which guides him in each of his succeeding lives.

In treatise III.4 Plotinus seemingly masters the ability to comment the texts of the second kind which are controversial in their contents. One can conclude that the treatise is a commentary in its 
purest forms already from the fact that 61 out of the 161 lines of the treatise include the quotations of Plato mainly from the three works mentioned above. (On the other hand, it could be considered quite normal, since Plotinus has always pointed out that his philosophy is nothing but the commentary to Plato's work.)

Plato writes in Timaeus (90a):

Speaking about the main part of the soul that is in us, about the part which occupies, so to speak, the crown of the body, we have to bear in mind that god has given it to every one of us as a daimon; we argue that it lives in the upper part of our body and raises us from the earth towards our heavenly relations, because we are not the earthly but a heavenly plant. And we have every right for that.

Daimon is a part of soul here, the prevailing part.

In the myths of Republic and Phaedo, however, daimon is an extraspiritual creature. How does Plotinus settle that problem? How does he answer to the question whether it is possible that the daimon of one person is a god?

The treatise consists of six chapters. Under the first two Plotinus makes an attempt to formulate the theory of soul, which is, accordingly, a theory of the hierarchical multiplicity of the abilities or forms of one and the same soul, starting from the abilities which reach Intellect, up to its vegetative potent.

In Chapter 2 Plotinus says that the human soul has the abilities corresponding to every level of existence. He starts with the quotation of Plato: Soul traverses the whole universe in different forms at different times, ${ }^{14}$ elaborating it:

namely, either in the perceptive form or the rational or in this very growth form. For the dominant part of it makes the thing appropriate to itself, but the other parts do nothing, for they are outside. In man, however, the inferior parts are not dominant, but they are also present [---]. Therefore one must "escape" to the upper world, that we may not sink to the level of sense-perception by pursuing the images of sense, or to the level of the growthprinciple by following the urge for generation and the glutton- 
ous love of good eating, but may rise to the intelligible and intellect and god.

Respectively, Plotinus describes the line of reincarnation:

Those, then, who guarded the man in them, become men again. Those who lived by sense along become animals [---]. But if they did not even live by sense along with their desires but coupled them with dullness of perception, they even turn into plants; [--] and they were taking care to turn themselves into trees. Those who loved music but were in other ways respectable turn into song-birds; kings who ruled stupidly into eagles, if they had no other vices; astronomers who were always raising themselves to the sky without philosophical reflection turn into birds which fly high. [---] but one who has a lesser share of it a creature that lives in community, a bee or something of the sort. Who, then, becomes a daimon? He who was one here too. And who a god? Certainly he who was one here. For what worked in a man leads him [after death]. Since it was his ruler and guide here too.

We are whom we make ourselves. We may lead our lives as animals and be animals this way; we may contemplate as a divine intellect and be a divine intellect in this sense.

At the end of Chapter 3 Plotinus approaches the theory in a more general aspect. The soul is in fact "all things" in potentiality and with respect to the ability which is most active, it may exist on all the possible levels in the hierarchy of the reasonable beings.

For the soul is many things, and all things, both the things above and the things below down to the limits of all life, and we are

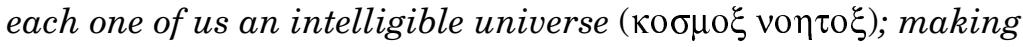
contact with this lower world by the powers of soul below, but with the intelligible world by its powers above and the powers of the universe; and we remain with all the rest of our intelligible part above, but by its ultimate fringe we are tied to the world below [---].

Therefore, in terms of one certain soul a daimon might be defined as an 'ability which is immediately higher of the ability which operates in the soul at a certain moment': that which is before the working principle; for this presides over the man, but that which 
comes after it acts. For the sensuous soul it would be, say, the intellectual soul, etc. As Plotinus puts it: We ourselves choose the daimon who controls us in our lives. Having made our choice, this potent will guide us and lead us further as a constantly intensifying dynamis, as a constantly intensifying energeia.

From that point of view the Plotinus' texts mentioned above are in accordance with each other, because our daimon would be a part of our soul, belonging to us, but still not being us. Hence it is understandable how we could become daimons - by our soul gradually ascending towards the higher and higher powers.

Eventually, we can find a solution to the question which - according to Porphyry - motivated the writing of the treatise: whether the daimon of a human can be a god? It is perfectly possible, because (1) the daimon is always a being of a superior level; (2) the soul of a man of wisdom reaches almost the intellectual reality which is on the level of the One, i.e. almost to the nous ['intellect'] and hen ['the One'].

Plotinus does not rule out the possibility of such a soul descending back here $(6,47 \mathrm{ff})$ :

But if the soul comes here again, it has either the same or another daimon according to the life which it is going to make for itself. It embarks, then, with this daimon first of all in this universe as if in a boat, then the physis [---] takes it over and sets it, just as in a ship, in some seat of fortune. And as the circuit of heaven, like a wind, carries round the man sitting, or even moving about, on the ship, there occur many and various sights and changes and incidents, and, just as in the actual ship, [they occur because] he is moved either by the tossing of the ship or by himself [---]. For everyone is not moved and does not will or act alike in the same circumstances. So different things happen to different people as a result of the same of different occurrences, or the same things to others even if the circumstances they encounter are different; for that is what destiny is like.

The line of reasoning undoubtedly provokes several questions. Can such a decline and ascent not have happened at all? Does the choice of a soul always guarantee a desired effect? What did Plotinus consider as the contents of his 'providence'? What are the limits of 
'freedom' in the light of his treatment of daimon? These questions, however, demand a more extensive study.

Plotinus' treatment of daimon had no distinct impact on either his immediate disciples nor the later Platonic tradition. "An atrocious demonology dominates"15 in Porphyry's works, where evil daimons approach the humans disguised as animals, all the houses are filled with them. The bodies are full of them when a human has his meals, etc.

Proclus (412-485), one of the most influential Neoplatonists, denies the existence of the evil daimons, even though his system includes the lower-class senseless corporal ghosts who (or which) torture the souls drowned in the matter. ${ }^{16}$

Astronomers referred to the terrifying death of Plotinus with content and construed it as a just retribution for his blasphemic disrespect towards the stars. ${ }^{17}$ Presumably, the demonologists could not remain quite indifferent about it either.

In sum we could mention that Plotinus' treatise III.4 is quite characteristic to his teaching. Once again the treatise draws our attention to the fact that the connections between the notions and their meanings are of greater importance to Plotinus than the clear limits of the notions. In the hierarchy of his hypostasis the dynamis, energeia and moving towards hen are much more meaningful than the exact limits of hypostases. And even all the limits become apparent only in motion.

Translated by Kait Realo

\section{Comments}

${ }^{1}$ So far the most thorough summary of the philosophy of Plotinus in Estonian: A. H. Armstrong. Plotinose õpetused ja kirjutised. Akadeemia, No 5, 1993, pp. 959-970. The same issue provides the translations of two treatises of Plotinus (pp. 923-948): On Beauty (Ennead I.6) and On the Intelligible (Ennead V.8). The best introduction in English is probably: D. O'Meara Plotinus (see comment No. 5 below)

2 The influence of Plotinus can not be restricted to the Christian tradition only. Its larger scope (and characteristic features similar 
to the other lines of thought) might be illustrated by complete works: Neoplatonism and Indian Thought. Ed. by Richard B. Harris. Norfolk 1982, Neoplatonism and Islamic Thought. Ed. by Parviz Morewedge. Albany 1992; Neoplatonism and Jewish Thought. Ed. by Lenn E. Goodman, Albany 1992. The bulky works (400-500 pp.) mentioned have been published in the series Studies in Neoplatonism (II, III, and VII volumes respectively).

3 Plotini opera, tom. I-III. Edierunt P.Henry et H.-R. Schwyzer. Paris, Bruxelles: Desclee de Brouwer, 1951-1973 (Museum Lessianum. Series Philosophica, 33-35).

${ }^{4} \mathrm{H}$. J. Blumenthal. Plotinus in the Light of Twenty Years'Scolarship, 1951-1971. Augstieg und Niedergang der römischen Welt, Teil II, Bd. 36, Teilbd. 1. Berlin, New York: Walter de Gruyter. 1987, pp. 529 .

5 D. O'Meara. Plotonius. An Introduction to the Enneads. Oxford: Clarendon. P. 1995, pp. vii.

${ }^{6}$ Lexicon Plotinianum. Ed. by J. H. Sleeman and G. Pllet. Leiden: Brill 1980 (Ancient and Medieval Philosophy, De Wolf-Mansion Centre, I, 2).

7 This kind of situation is most evident in the bibliographies of Plotinus: H. J. Blumenthal. Op. cit. pp. 528-570; K. Corrigan, P. O'Cleirigh. The Course of Plotinian Scholarship from 1971 to 1986, Ibid. pp. 571-623.

${ }^{8}$ Here and below the Greek form daimon $(\delta \alpha \mu \omega \omega)$ is used as the term is not exactly equal to the Christian term demon. The notion daimon denoted first and foremost a personal guiding spirit who leads a person's life, controls his fate and fulfills his destiny, who also guides the soul of the deceased to where it belongs. Finding a daimon the soul choses the daimon and not the other way around.

${ }^{9}$ M. P. Nilsson. Geschichte der griechischen Religion. Bd. 2: Die hellenistische und römische Zeit. 4. Aufl. München: Beck 1988. Handbuch der Altertumswissenschaft.

${ }^{10}$ E. R. Dodds. The Greeks and the Irrational. Berkeley, Los Angeles, London: University of California P. 1951, pp. 289. Sather Classical Lectures, Vol. 25. 
11 Olympiodorus. In Platonis alcibiadem commentarius. Initia philosophiae ac theologiae ex Platonicis fontibus ducta. Edidit Fr. Creuzer. Pars II. Francofurti: In officina Broenneriana. 1821, pp. 20.

${ }^{12}$ Cf. for example Apuleius. De deo Socratis, ch. 11; Porphyrios. De abstinentia, II.39.

13 E. Bréhier. Notitce. Plotin, Ennéades, t. III. Paris: Société d'Edition Les Belles Lettres. 1925, pp. 61 (Collection des Universités de France).

${ }^{14}$ Platon. Phaidros, 246b.

${ }^{15}$ Nilsson, M. P. Op. cit., pp. 438.

${ }^{16}$ Ibidem, pp. 460.

17 E. R. Dodds. Op. cit., pp. 262. 